\title{
WestVirginiaUniversity
}

THE RESEARCH REPOSITORY @ WVU

West Virginia Agricultural and Forestry Experiment

Davis College of Agriculture, Natural Resources

Station Bulletins

And Design

$1-1-1902$

\section{Vegetable gardening in the mountain glades}

L. C. Corbett

Kary Cadmus Davis

Follow this and additional works at: https://researchrepository.wvu.edu/

wv_agricultural_and_forestry_experiment_station_bulletins

\section{Digital Commons Citation}

Corbett, L. C. and Davis, Kary Cadmus, "Vegetable gardening in the mountain glades" (1902). West Virginia Agricultural and Forestry Experiment Station Bulletins. 81.

https://researchrepository.wvu.edu/wv_agricultural_and_forestry_experiment_station_bulletins/81

This Bulletin is brought to you for free and open access by the Davis College of Agriculture, Natural Resources And Design at The Research Repository @ WVU. It has been accepted for inclusion in West Virginia Agricultural and Forestry Experiment Station Bulletins by an authorized administrator of

The Research Repository@WVU. For more information, please contact ian.harmon@mail.wvu.edu. 
Digitized by the Internet Archive in 2010 with funding from Lyrasis Members and Sloan Foundation 


\section{WEST VIRGINIA UNIVERSITY \\ AGRICULTURAL EXPERIMENT STATION, \\ MORGANTOWN, W. VA.}

Bulletin 81.

APRIL, 1902.

\section{Vegetable Gardening \\ IN THE}

Mountain Glades.

By L. C. Corbett and K. C. Davis.

[The Bulletins and Reports of this Station will be mailed free to any citizen of West Virginia upon written application. Address, Director of Agricultural Experiment Station, Morgantown, W. Va.] 


\section{THE REGENTS OF THE WEST VIRGINIA UNIVERSITY.}

NAMF OF REGENT.

HoN. W. J. W. COWDEN

Hon. C. M. BABB

Hon. J. B. Finley

Hon. D. C. Galiaher

Hon. E. M. Grant

Hon. J. M. Hale

Hon. C. E. Haworth

Hon. C. R. Oldham

Hon. J. R. Trotter
P. O. ADDRESS.

Wheeling

Falls

Parkersburg Charleston

Morgantowr

Princeton

Huntington

Moundsville

Buckhannon

President of the Board of Regents - - IV. J. W. Cowden President of the University - - - - D. B. Purinton Treasurer - - $\quad$ - $\quad$ - $\quad$ - $\quad$ - A. R. Whitehill Auditor - - - - - - - - W. J. White

\section{STATION STAFF.}

Jamez H. Stewart, A. M. - - Director and Agriculturist A. D. Hopkins, Ph. D. - Vice Director and Entomologist Bert H. Hite, M. S. - - - - - - Chemist K. C. Davis, Ph. D. - - - - - - Horticulturist W. E. Rugsey, B. S. Agr. - - Assistant Entomologist Horace Atwood, M. S. Agr. - - - Assistant Agriculturist Chas. D. Howard, B. S. - - - Assistant Chemist F. B. Kunst - $\quad-\quad$ - $\quad$ - $\quad$ Assistant Chemist E. S. Stalvaker, A. B. - - - Assistant Chemist Gilbert M. John - - - $\quad$ Assistant Horticulturist John B. WALlace - $\quad$ - $\quad$ - $\quad$ - $\quad$ - Bookkeeper M. A. Stewart - - - - - - - - Librarian

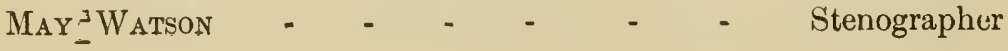




\section{PREFACE.}

The experiments which are described in this bulletin were begun in the Spring of 1899, and were pursued for two seasons under the direstion of Prof. L. C. Coibett, who was at that time Horticulturist to this Station, and who resigned in April, 1901.

The notes of the first two seasons' work have been furnished by Prof. Corbett since severing his connection with the Station. The experiments were continued through the season of 1901, and Prof. K. C. Davis, who came to the Station as Horticulturist in July, 1901, has extended the notes to include the results and teachings of the last year, and edited the other notes so as to express the conclusions of the three years taken as a whole.

J. H. Stewart, Director. 


\section{CONCLUSIONS.}

The three years of continuous experiments in Vegetable Girdening in the Nountain Glade Lands show very encouraging results.

The region compares to great advantage with the very best regions for raising vegetables in America.

Cabbage, onions and squashes, as herein reported, give unusually large yields without more care and expense than is usually given to the raising of those crops in our best commercial gardens.

Gardening in the glades of the Allegheny mountains is commercially profitable. Yields of good varieties are large, and of such superior quality as to command the best market prices.

Tile-draining is necessary for the lower glade lands. By use of tile, thousands of acres in West Virginia may be reclaimed.

Fall plowing without harrowing until Spring puts this soil into a much better physical condition for early Spring than if the deep tillage is left till Spring.

The store of plant food which this soil contains is made available by the use of lime. Thirty bushels to the acre was a decided benefit in almost all instances.

Lime, 30 bushels per acre. proved as valuable as about 1,000 pounds per acre of complete commercial fertilizer.

This soil gives increased yields of onions and cabbage when treateri with commercial fertilizer very rich in nitrate.

Stable manure gave the best results in a dry season by aiding the soil in the retention of moisture. On the other hand, in a time of heavy rains it may cause the soil to hold too much moisture and cause spasmodic growth, cracking of cabbage and rotting. 
In the tests of twenty-three varieties of cabbage, Filderkraut, Louisville Drumbead and Acme Flat Dutch gave the best yields and proved to be desirable for both local and general markets.

The region is adapted to the growing of late rather than early crops of cabbage, as the ground becomes warm enough for seed planting in the latter half of May.

The danger of slub root makes it inadvisable to plant cabbage on the same soil two years in succession. The disease is not yet developed in the glade lands.

Growing onion seerllings in hot bed and then transplanting to these glade lands is not commercially profitable. Seed drilled in the garden in early Spring usually pays better-allowing nothing for the cost of hot bed.

Of the eight varieties of onions tested, the Southport White Globe is best suited to such lands. It is of good quality, stands handling well, and gave a maximum yield of 456 to 480 bushels per acre.

Results indicate that continuous cropping of onions from same land might be detrimental, certainly so if no fertilizer is used.

The growing season in the glades is sufficiently long to produce mature crops of most of the varieties of squashes tested.

Of the nineteen varieties of squashes tested, the three yielding best were Boston Marrow, Golden Hubbard, and Livingston Pie. 


\section{ALLEGHENY MOUNTAIN GLADES.}

There are many depressions at high altitude in the Allegheny mountains, where the mountain stream; and rains have washed the richest soil from the surrounding elevations. These depressions, called Glades, vary in extent from a few acres, up to several thousands of acres. They are found about the head waters of a number of the streams which have their sources in the mountains of West Virginia. Some of the most remarkable areas of this character are found in Pocahontas and Randolph counties, where the altitude approaches 3,000 feet. In Webster county are the Long and the Welsh glades. In Preston county are hundreds of acres of such land at an altitude of some 1,700 feet above ticle water.

'These lands being lower than the surrounding hills or mountains, are usually rather level, and are therefore rather wet. In fact. some or all of them, were at one time perfect bogs in the lowest places. Plant life has marched upon these bogs. The roots have held new soil constantly being washe 1 in. The annual lecay of leaves and other vegetable matter has grallually built up a deep, rich soil. This transition from bog to glade land is a continuous process. The largest boy yet remaining in the State is in Pocahontas colinty, and is one hundred acres or more in extent.

The glades are kept wet by the surface drainage and springs from the bordering hills, and through them slowly flow shallow, sluggish streams, which seek their way to form a part of some river system below. It is by means of these water courses that the glades are drained. Before man's influence is brought to bear 
upon these areas they are largely waste lands, overgrown with alders and other brush.

As the value of these extensive glade lands becomes better known they may be used for vegetable gardens on a large scale. The general markets of the east, as well as the superior markets of our mining and marufacturing centers, are so near at hand that the question of local transportation seems to be the only one. This, however, is being solved very rapidly by the extension of railway lines, and by the improvement of country roads. The local transportation question will, therefore, soon be one of the past.

Two independent factors are now working toward the rapid reclaimation of the waste lands here described: First, knowlerlge of the value of the rich glade soil; how to make the plant food available for certair profitable crops, and how to drain and till the soil to bring forth best results. Second, the improved means for transporting the large yields to the best markets.

\section{THE GLADE LAND GARDEN.}

The ares here spoken of as the Glade-land Garden consists of some five acres of the flat: alluvial soil, on the farm of Mr. J. W. Guseman, of Preston county, West Virginia, and similar to that found in many portions of the Allegheny mountains, and syoken of as Glade-land.

Because of the flatness of the land and the shallowness of the water courses which cross it drainage is not easily accomplished. The soil is a dark muck, rich in organic matter, and impregnated with a small percentage of fine sand. The sand, however, is not present in sufficient quantity in most of these soils, to prevent them from baking and becoming difficult to pulverize, if worked wet. This surface soil is underiaid with clay at a depth of 15 to 18 inches, varying according to the position and conformation of the area. Atter drainage the soil yields readily to cultivation, assumes a good mechanical condition, and returns good crops of hay, wheat, corn and buckwheat without fertilization. When subjected to the demands of some of the more exacting garden 
crops, however, the returns indicate that the plant food in it is not in a readily arailable form. The problems here presented then are,-Given a soil composed of partially decomposed organic matter and other alluvial drift: (1) how can it be brought into proper mechanical condition to admit of its use for garden purposes; (2) How caw the store of plant food which this soil contains be made available, and (3) What are the crops best adapted to such soils and conditions.

PREPARATION OF THE SOIL.

'The land which came under the control of the horticulturist was not new land. It had been cleared and cultivated in cereals for several years, and was a new timothy sod when operations were begun upon it. The first work undertaken was a thorough system of tile drainage. The drains were dug $4 S$ feet apart and piped with two-inch agricultural tile at a maxiraum depth of two and one half feet below the surface. The ground was then thoroughly plowed ten inches deep and allowed to remain exposed to freezing and thawing during the winter. The following spring it was prepared for the reception of nnions, cabbage, squashes and celery. The first season's work was considered merely preparatory to the general scheme to be carried out on these lands, yet for the sake of a continuous record and at the same time to show the changes in the productiveness of the iand under intensive culture the records for the three years are includod in this report. The drains served theil purpose well, the surface soil came into tillable condition earlier in the spring than that of the neighboring hill land, which naturally contains a large percentage of sand and gravel. The digestive action of the winter's freezing broke down the soil particles and the result was that the desired mechanical condition was easily and quickly secured. The problem of mastering the mechanical condition had been solved. The one precaution necessary is to allow the drains time to act before going upon the soil in the spring. Working the soil while too wet is as injurious with these allurial deposits as it is with the heavy sedentary clays of the "Barren Coal Measures." Nothing is ever gained by cultivating the soil when too wet. The time gained in the 
spring by too early planting is usually paid for at a high rate in the yield of the crop.

\section{SPECIAL CROPS.}

The object of the work in the glade-land garden is to determine the crops which can be grown and which will yield a suffi. cient return to justify the owners of such lands in going to the expense of clearing and draining them. While the conclusions stated in this bulletin should not be taken as final proof in all cases. the work upon which they are based has been carried on long enough and under a sufficiently great variety of conditions as regards clinuatic changes and fertilizers, to serve as a fairly safe guide for the handling of these crops upon such lands. 


\section{CABBAGE.}

PlaA of Test. - The following questions were submitted to this vegetable for reply: What combination of plant food must be applied to the soil in order to return largest crop? What varieties are best suited to the locality and what is the correct date for planting seed in the open for a late crop? What result will follow contintious cropping the same soil with cabbage?

\section{CABBAGE FERTILIZER TESTS.}

In order to get an expression from the cabbage crop in regird to the soil requirements of the region, a plat was set aside in 1898. It was dividerl into four equal parcels, each two rods long and about twenty rods wide. To one lime at the rate of 30 bushels per acre was applied; to two others the following mixture of plant foods:

Fertilizer No. 1. Nitrate of Soda 250 lbs. per acre. Acid Phosphate 600 lbs. per acre. Muriate of Potash $180 \mathrm{lbs}$ per acre.

Fertilizer No. 2. Nitrate of Soda 2.50 lbs. per acre. Acid Phosphate 400 lbs. per acrs. Muriate of Potash $100 \mathrm{lhs}$. per acre.

A fourth section was reserved as a check and received no fertilizer of any kind. 
Each of the four plats was crossed by the varieties of cabbage given in table 1.

Table I.—UABBAGE 1899-lbs. per plat.

\begin{tabular}{|c|c|c|c|c|}
\hline \multirow{2}{*}{ VARIETY. } & \multicolumn{4}{|c|}{ Treatment of Land. } \\
\hline & Iime. & Fert. No. I & Fert.No.2 & Check. \\
\hline I. Burpee's All Head & 54 & $5 \mathrm{I}$ & 54 & 40. \\
\hline 2. Burpee's Sure Head .... & 90 & 90 & 96 & 92.4 \\
\hline 3. Henderson's Succession.......... & $S_{7}$ & 84 & 51 & $97 \cdot 5$ \\
\hline 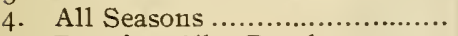 & 72 & 63 & 69 & 66. \\
\hline 5. Premium Flat Dutch............... & 72 & 63 & 69 & 65.7 \\
\hline 6. Filderkraut .......................... & 102 & 99 & I I I & I09. 2 \\
\hline 7. Stone Mason $\ldots . \ldots \ldots \ldots \ldots \ldots \ldots \ldots \ldots$ & 96 & 99 & 93 & 96.6 \\
\hline 8. Vanderyaw........... & 69 & 72 & 75 & $6 \mathrm{I} .5$ \\
\hline 9. Burpee's Safe Crop.. & 63 & 66 & 69 & 62.1 \\
\hline Io. Burpee's Short St. Drumhead.. & 54 & 60 & 63 & 47.1 \\
\hline I I. Burpee's World Beater............ & $7 S$ & 78 & 75 & 73.5 \\
\hline I2. Danish Bull Head.................. & 57 & 54 & 66 & $4.3 \cdot 5$ \\
\hline 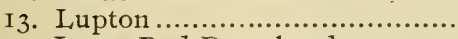 & 78 & 78 & $8 \mathrm{I}$ & 6S.I \\
\hline 14. Large Red Drumhead-...... & 33 & 36 & 33 & 30. \\
\hline I5. Mammoth Rock Red...... & 30 & 27 & 30 & $26 . I$ \\
\hline I6. I ate Flat Dutch.................... & 72 & 63 & 72 & 61.5 \\
\hline I7. Late Drumhead .................... & 69 & 63 & 66 & 63.6 \\
\hline I8. Louisville....................... & in5 & $\mathrm{IO} 2$ & IOS & 96.9 \\
\hline I9. Marblehead Mammoth Dutch.. & 34 & 87 & 87 & $\$ 6.1$ \\
\hline 20. Acme Flat Dutch................... & I I 8 & II 2 & II 4 & 96. \\
\hline 2I. Perfection Drumhead Savoy.... & 42 & 42 & 45 & 37.8 \\
\hline 22. Fowler's Brunswick............... & 93 & 90 & 96 & 90.3 \\
\hline 23. Belleville Savoy................... & 33 & 33 & 36 & 30. \\
\hline Total for all & I650 & I6I2 & I66o & I 535.5 \\
\hline
\end{tabular}

The seed in every case was drilled in after the fertilizers were distributed upon the ground. The rows were three feet apart and the plants thinned to stand three feet apart in the row. Clean culture was given, and as the season was a favorable one the growth was satisfactory and the field at harvest time presented the condition shown in Fig. 2.

From the character of the fertilizers used it will be noted that lime, which adds no plant food to the soil and which influences the crop only by acting upon and setting free plant food already in the soil, produced in nearly every case and in the total an 
increased crop over the sheck, Nus. 2, 3, 6, 7 and 19 proving the only exceptions.

A comparison of the lime tests in table 1 with fertilizer No. 1 shows that, notwithstanding the fact that fertilizer Yo. 1 carried into the soil over one-half ton per acre of the standard constituents of commercial fertilizers, yet the limed area gave yields equal to, or exceeding those of the fertilizer plat in all cases except Nos. 8, 9, $10,14,19$. This would indicate that for soils containing a large percentage of organic matter lime applied at the rate of 30 bushels per acre is equal to 1030 pounds of commercial fertilizer in the form of fertilizer No. 1.

By comparing the figures in the column of fertilizer No. 1 with the check plat column, we find that the use of the fertilizer increased the total yield nearly one-half per cent. Six varieties, where there is a difference favoring the check plat, cut this pereentage down.

Fertilizer No. 2, as shown by Table 1, increased the yield of al] sorts over Fertilizer No. 1, except in the case of the third variety. This would tend to show the importance of adding nitrogen the first year as a plant food for cabbage rather than phosphoric acid or potash. The nitrogen exists in the same form (nitrate) in both fertilizers (Nos. 1 and 2) but in No. 1 there is 3.8 per cent. of nitrogen while in No. 2 there is 5.3 per cent. While the same variety shows variation under the different treatments, yet there is a greater variation between varieties. While the verdict - sorts is somewhat contradictory, the totals for all are better for somparison.

\section{CABBAGE THE SECOND YEAR.}

The results of the first year were not sufficient to justify final conclusions regarding the value of the fertilizers used in the tests, and the experiments were continued for two more seasons. It is only fair to state at the outset that the 1900 season was one of unprecedented drouth in the region. All vegetation was backward and the yield in consequence grtatly reducerl. This was true not only for cabbage, which is a great lover of moisture, but also for forage crops generally. 


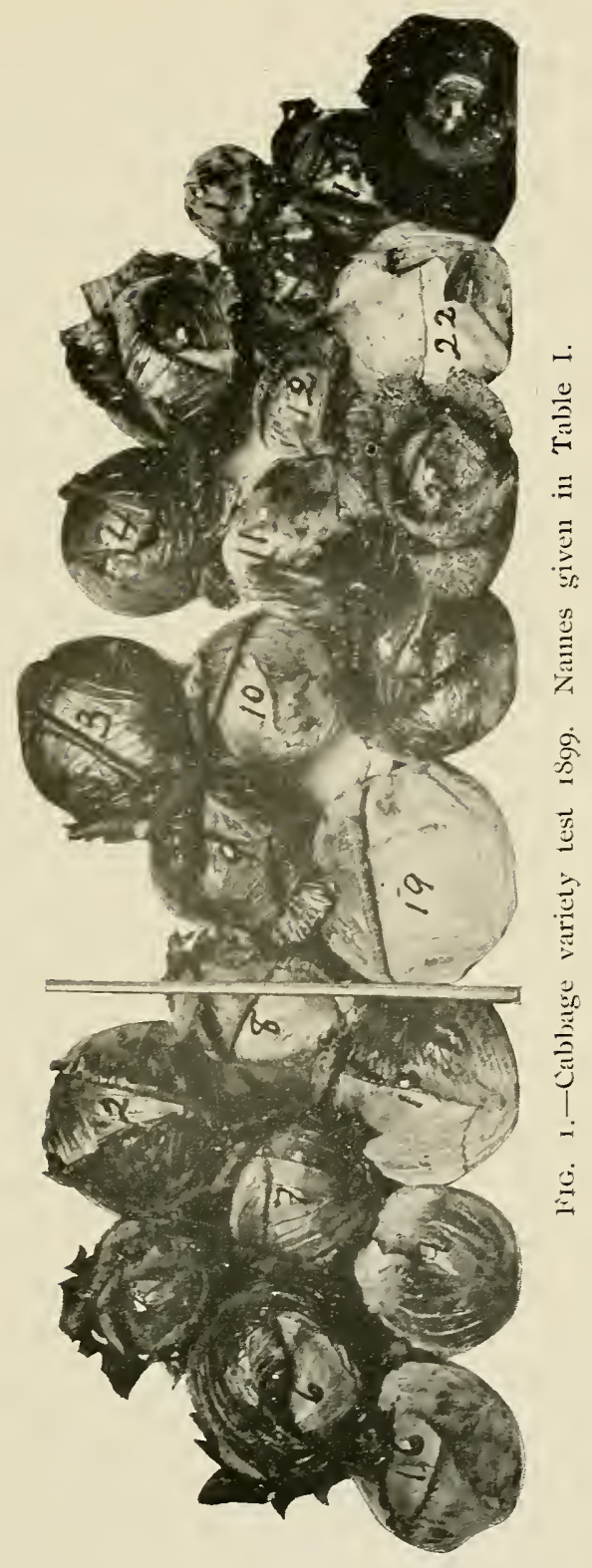



Table II._CABBAGE 1900-Lbs. Per Plat.

\begin{tabular}{|c|c|c|c|c|c|}
\hline \multirow{2}{*}{ VARIETY. } & \multicolumn{5}{|c|}{ Treatment of Land. } \\
\hline & Lime. & Fert.No.I & Fert.No.2 & $\begin{array}{l}\text { Stable } \\
\text { Manure. }\end{array}$ & Check. \\
\hline Early Dwarf York.......... & IS & 29 & 23 & 28.5 & 9. \\
\hline Early Weiningstadt....... & 28 & 44 & 36 & 53. & 24. \\
\hline Danish Ball Head.......... & 26 & 34 & 31 & 43. & $2 \mathrm{I}$. \\
\hline Large Early York... & 23 & $3 \mathrm{I}$ & 27 & 38.5 & I7. \\
\hline Early Blood-red Erfurt... & IS & I9 & IS & 32.5 & 12. \\
\hline The Vanderga w............... & $4 I$ & 48 & $4 I$ & 59. & 35 . \\
\hline Early Dwarf Flat Dutch.. & 27 & 36 & 32 & 48.5 & 23. \\
\hline Large Wakefield............ & 38 & 42 & $4 \mathrm{I}$ & 54.5 & 32. \\
\hline Late Flat Dutch............. & $5^{8}$ & 68 & 62 & 78.5 & 42. \\
\hline $\begin{array}{l}\text { Total for all ( I }-44 \text { acre)... } \\
\text { Calculated for I acre..... }\end{array}$ & $\begin{array}{r}277 \\
\text { r } 2198\end{array}$ & $\begin{array}{r}35 \mathrm{I} . \\
\mathrm{I} 5444\end{array}$ & $\begin{array}{r}31 \mathrm{I} \\
\mathrm{I} 684\end{array}$ & $\begin{array}{r}436 . \\
19184\end{array}$ & $\begin{array}{l}213 . \\
9460\end{array}$ \\
\hline
\end{tabular}

The yields shown in table II do not compare very favorably with those reported for 1899 on the same ground. ". hile this difference m.ty be accounted for on the basis of moisture, it is possible that we have here an indivati $n$ of what we may expect from the continued growth of caubage on the same ground. Whatever the cause, the yields are much less than in 1899, yet the verdict of the test as a whole is much more pronounced than in 1899 . It will be noted that an additional plat has peen brought into the test, $i$. e., a plat upon which 20 tons of stable manure were used per acre. In comparing the lime plats with the check the marked effect of the lime becomes at once evident as does also the very decided influence of both Fertilizer No. 1 and No. 2. There is this time no uncertainty in regard to the position occupied by the various materials. Lime is markedly superior to (check) no fertilizer; fertilizer No. 1 is markedly superior to No. 2, while the 30 ton application of stable manure gave a decidedly increased yield over any of the other treatments. In this case it is also notable that the variety characteristics are preserved through all treatments. For instance. Late Flat Dutch returned the largest yield under all treatments, while Early Blood-Red Erfurt returned the smallest yield in all cases except on the check and stable mautre 
plats. The total product of a given treatment for all varietics is given at the bottom of table II. Lime increased the total yield 62 lbs., Fertilizer No. 1, 136 lbs., Fertilizer No. 2, 96 lbs., while stable manure gave an increase of $221 \mathrm{lbs}$. If the plant food furnished by each of the materials be taken into account an idea of the crop producing power of eash combination will become apparent. The total area of the plats for all varieties was one-fortyfourth of an acre. With the above as a basis we find the yield per acre to be:

Lime. - - - 12189 lbs., gain over check plat 5728 lbs.

Fert. No. 1. - 15444 lbs., gain over check plat 5984 lbs.

Fert. No. 2. - - 13684 lbs., gain over check plat 4224 lbs.

Stable manure. - 19184 lbs., gain over check plat $9720 \mathrm{lbs}$.

Check. - - . 9460 lbs., gin over cheek plat 0000 lbs.

Stable manure 20 tons per acre would carry to the land 196 lbs. nitrogen, $128 \mathrm{lbs}$. phosphoric acid, and $192 \mathrm{lbs}$. of potash valued at 12,4 , and 3 cents per lb., respectively. The value of the stable manure would be $\$ 32.80$ which produced the first year an increased crop of $9723 \mathrm{lbs}$. per acre or $\$ .0032$ per ll). for the increased crop. Fertilizer No. 1 produced an increased crop 5984 lbs. at an expense of $\$ .0019$ per $1 b$; while test No. 2 produced 4224 lbs. increase at a cost of $\$ .001 \mathrm{~S}$ per $1 \mathrm{~b}$.

Allowing for no effect of the stable manure on next season's orop and no accumulative effect on fertilizer plats 1 and 2 from the use of these manures during the previous years, then the commercial fertilizer prorluced its increase for about two-thirds the cost of the increase secured from the use of stable manure. In all instances :t is more than likely, as shown by the $190 \mathrm{I}^{-}$yields, that there is an after influence of the application of fertilizer. It is svilent, however, that for quick returns on soils naturally containing large quantities of organic matter, that market gardeners act wisely when they largely employ chemical manures, provided there is an average rain-fall well distributed through the growing season. 'The char'zeter of the season can never be forecasted. The gardener, theiefore, must take advantage of all known means to counteract ill effects of lrouth. The one advantage of decaying 
organic matter such as leaf mould and stable manure, is its ability to conserve moisture and act as a benefit to plants during periods of drouth. Its mechanical effects in this direction may be equal to its value as a plant food. On the other hand, during periods of heavy rain a surplus amount of decaying moisture in the soil may hold too much moisture. This is detrimental to crops which require a uniform growth. Spasmodic growth in cabhage is apt to burst the heads, as was the case on the plat with stable manure in 1901.

\section{CABBAGE THE THIRD YEAR.}

The same area which had been used for cabbage the two years preceding was, in 1901 planted with one variety of cabbage, Late Flat Dutch. The yield was remarkable. The results are shown in table III, which gives the number of pounds per plat of five square rods. Several points are to be gained by the season's work.

Table III-Cabbage. 1901.

\begin{tabular}{|c|c|c|c|c|c|}
\hline \multirow{2}{*}{ VARIETY. } & \multicolumn{5}{|c|}{ Treatment of Land. } \\
\hline & Lime. & Fert.No.I & Fert. No.2 & $\begin{array}{c}\text { Stable } \\
\text { Manure. }\end{array}$ & Check. \\
\hline $\begin{array}{l}\text { Late Flat Dutch. } \\
\text { Yield for } 5 \text { sq. rods. ...... } \\
\text { Calculated for I acre..... }\end{array}$ & $\begin{array}{r}610 \\
19520\end{array}$ & $\begin{array}{r}75^{8} \\
24256\end{array}$ & $\begin{array}{r}691 \\
22 I I 2\end{array}$ & $\begin{array}{r}405 \\
\mathrm{I} 2960\end{array}$ & $\begin{array}{r}600 \\
19200\end{array}$ \\
\hline
\end{tabular}

Continued liming of the same area for three years increased the yield less the last year than in either of the preceding vears. Fertilizer No. 1, the third year, increased the yield over thirty per cent. as compared with the cherk plat. Fertilizer No. 2, applied for the third season on the same land, increased the yield over check 91 pounds or only fifteen per cent. This reversal of the results with the two commercial fertilizers the third season goes to show that the glade soils are already fairly well supplied with nitrogen in forms which are not readily available for plant food, but which become available after the soil is treated by under drainage and tillage.

The low weight taken from the stable manure plat is explain- 
ed by the fact that the heavy rains of early fall started a sudden growth which cracked the heads. The rot, which soon followed, destroyed nearly half of the crop. The other plats were not troubled in this way. The soils treated with stable manure hold the most moisture and in this case became too wet.

\section{CABBAGE VARIETY TEST.}

By table I we are given an idea of the behavior of some twenty-three sorts when subjected to the same treatment and are enabled to select those which produce the best return per acre. Fig. 1 gives an accurate idea of the form and character of the different sorts. This in comparison with table I reveals that Nos. 6, 18 and 20 stand at the head as regards yield and at the same time are of a type most desirable for home market or shipment. Following these sorts are Nos. 7, 22, 2, 3, 19 and 13 . Other sorts turned a crop not as large as the above named by twenty per cent., and show no marked superiority either in form or quality to warrant their culture in preference to Filderkraut, Louisville DrumHeal, Aime Flat Dutch for first class; Stone Mason, Fowler's Brunswick, Burpee's Sure-Head, Henderson's Succession, MarbleHead, Mammoth Drum-Head, and Lupton, as a close second group.

\section{CULTURAL DIRECTIONS.}

Cabbage is grown commercially both as a summer and autumn erop. Plants for the early crop are grown from seeds sown in October or November. The young plants in the vicinity of Norfolk, Virginia, and southward are planted out the last of November in the lee of a furrow, protected with a shingle or left without protection according to location and exposure. Such plants are in condition to take advantage of the first warm days of spring and thus produce a very early crop. Ir localities where the winter conditions will not admit of this method of treatment, the young plants grown from seed sown in October are wintered in cold frames. The cold frames should be placed on the sheltered side of some structure, the sash lifted during mild days even in midwinter, and as soon as the warm days of early spring come sbould 


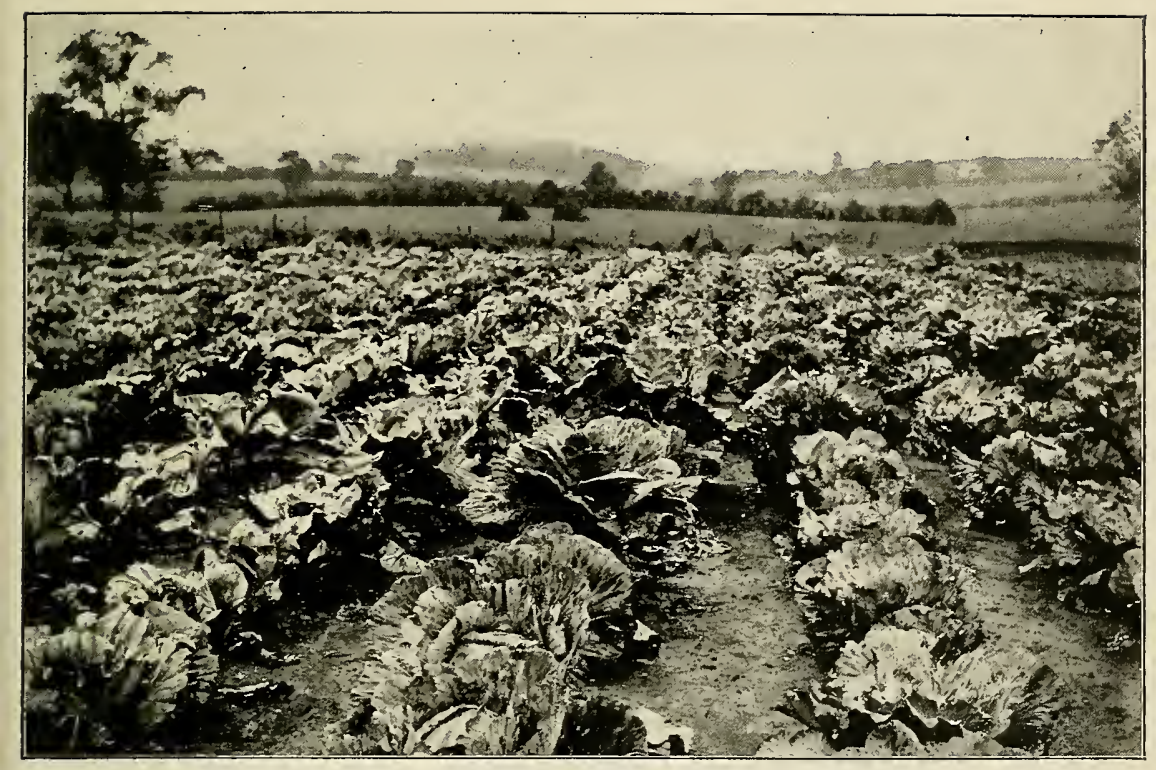

FIG. 2.-Cabbage plats at harvest time.

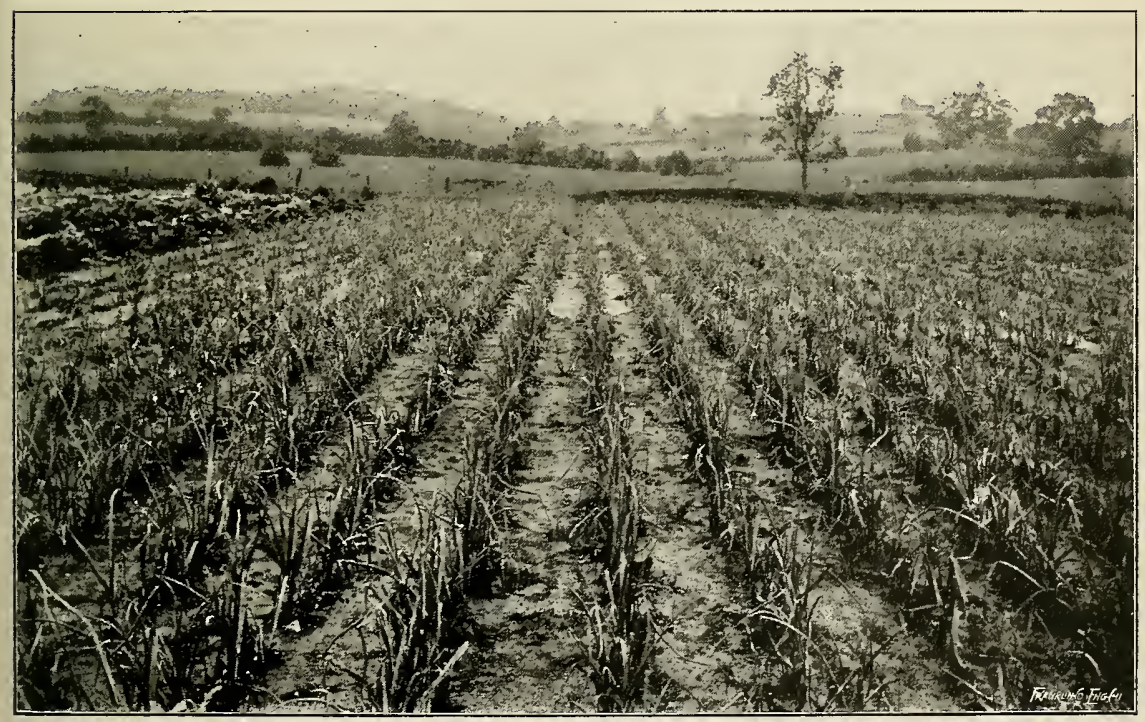

FIG. 3.-Onion plats in glade garden. 

be removed entirely. The precaution of replacing them at night should be observed until all danger of severe freezing is past and until the plants have become thoroughly hardened. Land which has been thrown up into ridges with the lister after plowing in the fall will come into order much quicker than land not so treated. By so treating the soil the early crop of cabbage can be set in the field several weeks in advance of that to be set on spring prepared land. For the early crops the plants should stand 18 inches apart in the row with the ruws about two and oile-half feet apart. Frequently gardeners plant exrly cabbage between the rows of spinach, as soon as the spinach is marketed the land becomes entirely available for the cabbage.

The late crop of cabbage is one of greatest importance in the home garden as well as a farm crop. Late cabbage is usually grown from seed sown in the field where the crop is to mature. Planting in West Virginia may be done any time bətween May 15 th and June 1st. The seed being sown in rows two and onehalf or three feet apart with the ordinary garden seed drill or with a hill and drill dropping machine. As soon as the young plants are thoroughly established they should be thinned to stand at least two and one-half feet apart in the row. From this time on both with plants grown from seed sown in the field, as well as from transplanted plants frequent shallow cultivation should be given. No garden or farm crop responds more readily to liberal treatment, both as regards culture and fertilizer, than does cabhage. In order to produce cabbage of the highest quality it should never suffer a check from the time it is put in the field until it is harvested. A continuous rapid growth is productive of best results but a continuous slow growth is much better than intermitteit periods of growth, as the latter behavior is apt to produce a large percentage of cracked heads. If a dry summer is followed by a rainy fall a late and rapid growth is certain to result. Such was the case on the manured plat in 1901. The precaution of loosening the plants by tipping them to one side or cutting off a part of the roots is sometimes resorted to. Such a 
treatment reduces the food supply and gives the plant an opportunity to more slowly adjust itself to the changed conditions.

\section{ENEMIES AND DISEASES.}

The cabbage plant is made the chief source of food supply by three annoying insects. As swon as the young seedlings appear above ground they are immediately besieged by a small black flea beetle, the same as is so destructive to young radish plants. This pest can be dealt with by mulching the young plants with tobacco dust. As the plants increase in size they are abandoned by the flea beetles only to become the host plants for the cabbage worm. This is an annoying pest and one difficult to deal with except by the use of Kerosene Emulsion or l'aris Green. If the latter is used it should be confined to that period prior to the development of the head, and then only at the rate of one ounce to ten gallons of water. After the heads are formed Kerosene Emulsion should be substituted for the Paris Green. The pest which is most difficult of all to treat is the Harlequin cabbage bug, a rather handsome creature nearly as large as a potato beetle. This bug iz difficult to combat because, like all true bugs, it takes its food by sucking. It can, therefore, only be killed by contact insecticides. This is difficult and at best an unsatisfactory operation, and growers have resorted to the scheme of planting food plants, which are preferrer by the bugs, as decoy crops between the rows of cabbage. As soon as the bugs have collected in large numbers on the decoy crop it is sprayed with pure kerosene which not only kills the bugs but the crop as well. The plant commonly used for this purpose is mustard. Cabbage if grown continuously on the same soil is apt to suffer from club root, a disease caused by a low parasitic plant known as Plasmodiophora brassisee. If the crop is rotated with grain crops or moved from place to place and the soil is not fertilized with manure in which diseased cabbage stumps have been thrown, there is little danger of the disease. In fact rotation is the only known remedy for the trouble.

\section{HARVESTING AND STORING.}

Cabbage is a hardy plant and the crop need not, therefore, be harvested early. If left in the field until the weather has 
grown frosty the product will keep better than it will if stored early. If the market will take the crop it is most economical to dispose of it direct from the field at harvest time. If for any reason it is desirable to hold the crop, select the highest and best drained land on the planted area, excavate a shallow trench wide enough for three heads of cabbage when placed side by side. Pull the plants and stand them heads down in the trench, on top of the three place two, and a third one on top of and between the stumps of the two, thus making a pyramid of cabbage with roots up. A heap of this width can be increased to any length desired, and for protection it can be covered with straw and earth, earth and boards or earth alone. The depth of the covering to be governed according to the severity of the weather. If the cabbage freezes, it should be kept frozen by the addition of earth or other protective material. Alternate freezing and thawing rather than freezing alone is destructive to stored cabbage. 


\section{ONIONS.}

The work with this crop was undertaken to test the adaptability of the crop to the region; to determine the character of the fertilizer best suited to the needs of the soil ; and at the same time to note the advantages, if any, of transplanting young onions from the hot-bed to the field, and the ill effects, if any, from growing the crop continuously on the same soil.

The onion crops of all three seasons have been very gratifying, both as regards the yield and quality of the product. The plants have grown well, produced a large percentage of well formed merchantable bulbs each season, and have so far escaped the blight until the season's growth was practically completer and the bulbs ready to harvest. To determine the demands of the crop as regards fertilizer, the following combinations were chosen:

1. Lime at the rate of 30 bushels per acre.

2. Fertilizer No. 1 composed of

Nitrate of Soda 270 lbs. peracre, Nitrate 4 per cent.;

Acid Phosphate 450 lbs. per acre, $\mathrm{P}_{2} \mathrm{O}_{5} 6$ per cent.;

Muriate Potash $160 \mathrm{lbs}$. per acre, Potash 9 per cent.

3. Fertilizer No. 2, composed of

Nitrate of Soda 300 lbs. per acre, Nitrate 8 per cent.;

Acid Phosphate 400 lbs. per acre, $\mathrm{P}_{2} \mathrm{O}_{5} 7$ per cent. ;

Muriate Potash $100 \mathrm{lbs}$. per acre, Potash 6 per cent.

4. Stable Manure, 20 tons pe: acre. (Omitted in 1899.)

5. Chesk plat, receiving no fertitizer.

Seven sorts of onions were used in the trial. These are named 
Table IV-Yield of Onions in Bushels Per Acre. -1899.

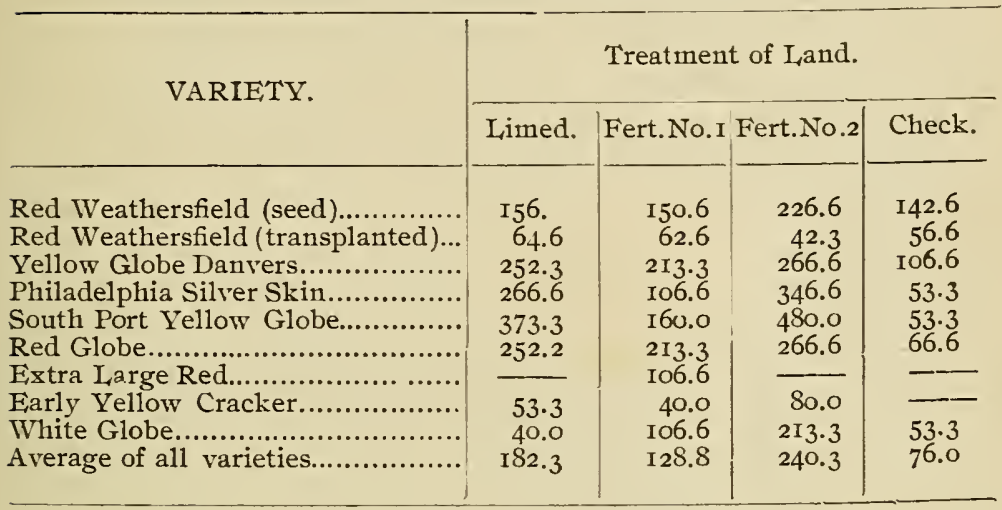

Table V.-Yield of Onions in Bushels Per Acre.-1900.

\begin{tabular}{|c|c|c|c|c|c|}
\hline \multirow{2}{*}{ VARIETY. } & \multicolumn{5}{|c|}{ Treatment of Land. } \\
\hline & Limed. & Fert.No.I & Fert.No.2 & $\begin{array}{c}\text { Stable } \\
\text { Manure. }\end{array}$ & Check. \\
\hline $\begin{array}{l}\text { I. Prize Taker (seed)..... } \\
\text { 2. ". (transpl’d) } \\
\text { 3. So. Port White Globe.. } \\
\text { 4. R. I. Yellow Cracker.. } \\
\text { 5. Yellow Globe Danvers } \\
\text { 6. Australian Brown....... } \\
\text { 7. Red Weathersfield...... } \\
\text { 8. Early Yellow Cracker } \\
\text { Average of all............ }\end{array}$ & $\begin{array}{l}320 . \\
173.2 \\
322 . \\
241.3 \\
227.5 \\
\text { I } 15.2 \\
\text { I } 57.3 \\
86.6 \\
205.4\end{array}$ & $\begin{array}{l}\text { II } 5.4 \\
100 . \\
409.3 \\
410.6 \\
293.3 \\
110.6 \\
145.3 \\
93.2 \\
209.7\end{array}$ & $\begin{array}{l}\text { I } 22.6 \\
\text { 100. } \\
346.6 \\
373.3 \\
306.6 \\
\text { I } 22.6 \\
\text { I56. } \\
\text { I } 15.2 \\
205.4\end{array}$ & $\begin{array}{r}301.2 \\
309.2 \\
456.6 \\
403.3 \\
414.3 \\
142.6 \\
213.3 \\
89.8 \\
291.4\end{array}$ & $\begin{array}{l}\text { I } 15.2 \\
\text { I } 33.2 \\
\text { I } 80 . \\
\text { I6o. } \\
\text { I33.2 } \\
40.0 \\
\text { I } 42.6 \\
\text { I00. } \\
\text { I25.5 }\end{array}$ \\
\hline
\end{tabular}

Table VI. - Yield of Onions in Bushels Per Acre.-1901.

\begin{tabular}{l|r|r|r|r|r}
\hline & \multicolumn{4}{|c}{ Treatment of Land. } \\
\cline { 2 - 5 } & Limed. & Fert.No.I & Fert.No.2 & $\begin{array}{c}\text { Stable } \\
\text { Manure. }\end{array}$ & Check. \\
\hline Average of all varieties... & 94.8 & 92.6 & I 26.8 & 366. & I7.4 \\
\hline
\end{tabular}


in the tables and the yield per acre is given. The figures showing yield of onions are emphatic regarding the effect of lime upon the glade-land soil as were also the figures concerning cabbage. Fertilizer No. 2 proved itself much superior to lime in 1899 and 1901, and when the yields of the areas treated with fertilizer No. 2 and the check (or untreated) area are compared, the value of this fertilizer becomes evident. In 1900 and 1901 another plat was treated with stable manure at the rate of 20 tons per acre. The comparative effect of the stable manure is shown by the yields recorded in tables $\mathrm{V}$ and VI. The column of figures under the heading Stable Manure is very striking, both when compared with those of the check plats as well as those of the commercial fertilizers. All four treatments are much superior to check (no fertilizer), while stable manure was markedly superior to all other applications. The action of lime on this soil is sufficient to justify the statement that the great need of this soil is something to make its stored plant food immediately svailable. The behavior of the gross feeding garden crops when subjected to a treatment of lime and stable manure proves this emphatically. For slow growing crops the difference is less apparent.

\section{CONTINUOUS CROPPING.}

The results with onions the third season show conclusively that continuous cropping, year after year, of the saine area is not advisable. The yields of all but the stable manure plat fell off very decidedly. The season was in most respects a favorable one, and the low yields 0.1 the four plats is accounted for by the continuous robbing of these soil ingredients which the onion is able to use. The increased yield on the stable manure plat shows that onions on this soil are abundantly well supplied with plant food by the application of this fartilizer. Continuous cropping on this plat was accompanied by no ill effects whatever.

TRANSPLANTING VS. FIELD SOWING.

The varieties used in this test were sown in the hot bed on the sarne date that the sced was planted in the field. The only advantage, if any, to be gained by the hot-bed-grown plants must therefore be in the quicker germination and more rapid growth afforded 
Check | Lime | Fert. No. I | Fert. No. 2 Stable Manure

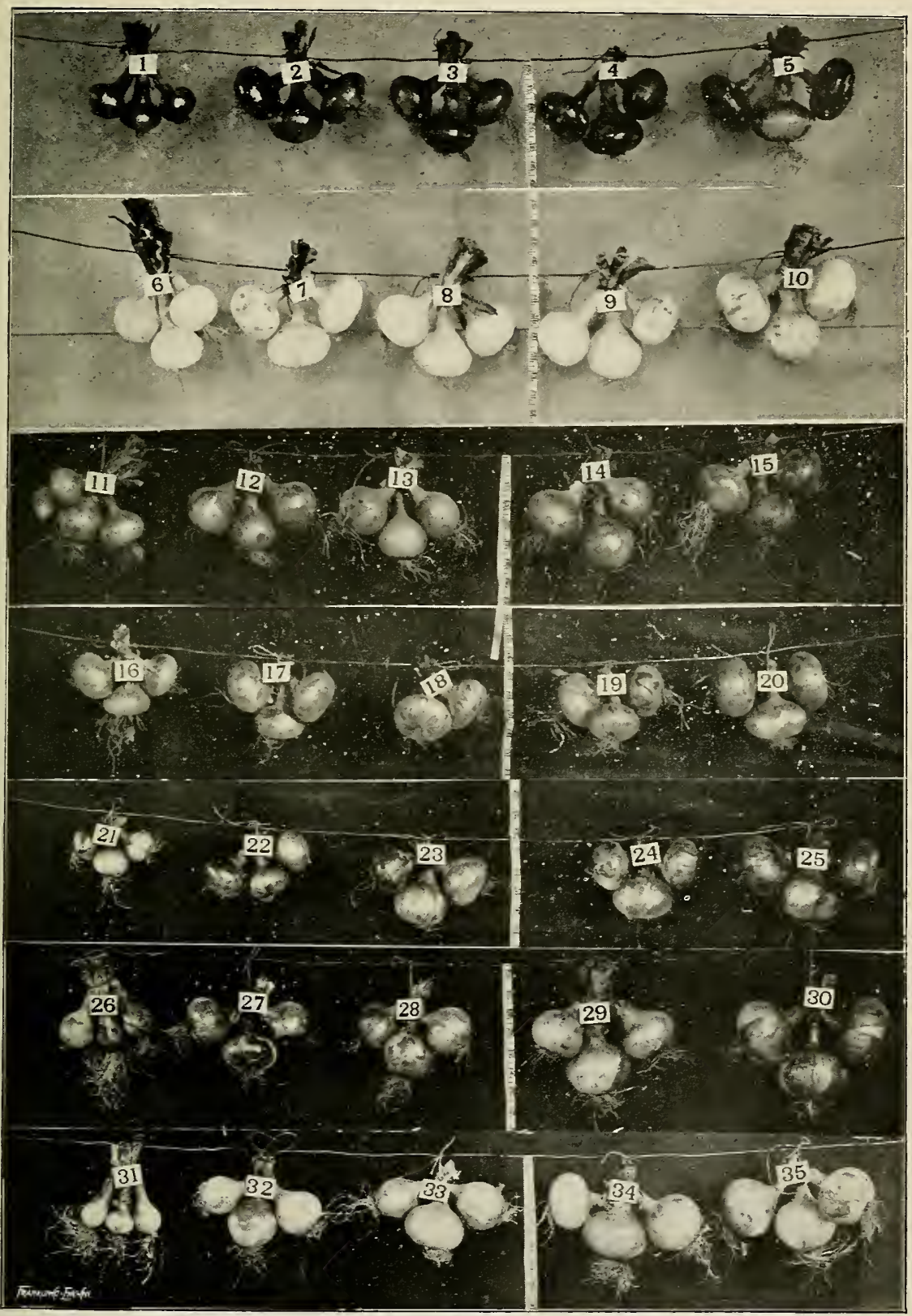

FIG. 4.- Varieties of Onions. I to 5, Red Weathersfield. 6 to ro, South Port White Globe. I I to I5, Yellow Globe I)anvers. I6 to 20, R. I. Yellow Cracker. 21 to 25, Australian Brown. 26 to 30 , Prizetaker field sown seed. $3 \mathrm{I}$ to 35 , Prizetaker hot bed sown seed. 

by hot bed canditions and the operation of transplanting. Red Weatherfield was used in 1899, and Prizetaker in 1900. The results confirm the statement that there is nothing to be gained by such treatment save in one instance, and even there the difference is not sufficient to justify. the necessary outlay for equipment. In the case of Prizetaker onions transplanted to the manured plat the yield of the transplanted block was greater than in the case of those grown from seed. In regard to the general value of the method of starting onions in the hot bed, it will not be out of place to call attention to the fact that the above recorded tests coroborate the results recorded in bulletin 47 of the South Dakota Station. In justice to Prof. IV. J. Green of the Ohio Station (Bulletin III:9,) and to Mr. T. Greiner, author of "New Or:ion Culture," it is only fair to state that these tests in no wise invalidate their claims for hot-bed seeding, as they were made from a different standpoint. The claims made for that method are well founded and are of great importance for persons with limited areas under culture.

\section{COMPARISON OF VARIETIES.}

The work of the three seasons has fully demonstrated the superiority of the Southport strains of onions for the conditions in the glade lands. In figure 4 the varieties are in horizontal rows; they are named in table $V$. The specimens from the same fertilizer plats are in vertical rows. Among the varieties grown, none of the white onions show the promise made by the Southport White Globe. The Philadelphia Silver Skin, produced well and gave a crop of high quality and appearance, but before the curing period was over many bulbs were badly discolored. They suffered greatly from handling and were poor keepers. The Southport White Globe, on the contrary, had none of these draw backs. Among the yellow, and so-called brown onions, the Southport Yellow Globe and the Rhode Island Yellow Cracker both proved valuable sorts. The yield was large, the flavor good, and the keeping qualities satisfactory. The large Red Weatherfield, among red onions, proved most satisfactory in all respects. It is a fair producer, mild flavored, long-keeping, good-appearing onion. 
Everything considered, our experience with onions has been most satisfactory. 'I'he soil lends itself readily to the culture of the onion and the elevation and rainfall seem well suited to its growth and maturity. Good judges pronounced the onions grown on this land as very superior in quality. The yields too, have been sufficiently large to justify the owners of glade-land in making the necessary expenditures to put the land in order for the culture of this crop. Onions seldom sell for less than 50 or 60 cents per bushel. At this rate a yield of 200 bushels per acre, even, will turn a gocd profit. The onion, of course, requires good treatment, but it pays well when such treatment is given.

\section{CULTURAL HINTS.}

Commercially the onion is usually grown from seed. This is usually planted in the spring, but because of the bardy nature of the plant and the long period necessary for its perfection. the land upon which onions are to be planted, must be prepared the fall before. If left rough plowed through the winter, the soil will be found to dry more quickly and come into order sooner than that harrowed in the fall after plowing. As soon as the soil will admit of cultivation in the spring, the surface preparation should be completed and the seed sown. If this can be dorie as early as February, so much the better. Ordinarily suitable conditions will prevail during March or early April. The first opportunity that offers after February 15th, should be taken advantage of to sow the seeds. Lay off rows 15 or 18 inches apart at right angles to the direction of tha prevailing winds, then with a horse or hand seeder sow new seed at the rate of $8 \mathrm{lbs}$. per acre. As soon as the young plants are up sufficiently to mark the rows start the hand cultivators, keep them going frequently to prevent weed growth, and for the purpose of maintaining a good mulch of loose surface soil over the field. This will not only stimulate growth in the onions by eliminating competition with weeds but it will tend to maintain a stipply of moisture in the soil to the advantage of the plant later in the season. As soon as the young plants are as thick as a rye straw they should be thinned so that only a single plant remains in a place. The thinned plants standing four inches 
apart in the row. Frequent shallow culture is the only other requisite between the time of thinning and maturity. If by the middle of August the bulbs do not show signs of maturity a light board roller or an empty barrel should be rolled over the patch to break down the tops and hasten maturity.

When harvest time arrives in September, the bulbs may be pulled by raking them out of the ground with a wooden-toothed rake with the teeth set close together. After pulling, the bulbs should be allowed to cure in the field some days, if the weather is mild, before storing. If the sun is hot it is not wise to allow the bulbs to lie exposed on the surface for any length of time, one or two days at most. As soon as the tops have dried, twist or shear them off, carry the onions to the store room and place them in layers on shelves or on the floor of a dry airy compartment, such as a barn or shed. Unless one has unusually good facitities for storing and holding the crop greater profit will accrue from marketing direct from the field. For shipment the bulbs should be placed in crates, baskets or barrels, rather than in bags, as the storage life of an onion is materially shortened by rough treatment. 


\section{SQUASHES.}

This plant is usually considered a long season crop. The question first suggesting itself was, can a profitable crop be matured in the Glades? If so, what variety or varicties are best suited to the region? The cultural tests with this crop while carried out on a small scale have proven so satisfactory during both seasons that we feel there is a great future for such an iudustry in this region. A glance at table VII, which gives the yield per acre of the eight sorts grown in 189:), is sufficient proof that squashes, even at a much smaller yield per acre, could be made a very paying crop. At one cent per pound the poorest yield would have returned $\$ 132.31$ per acre, while the best paid at the rate of $\$ 203.66$ per acre. With suitable transportation facilities this region can be made to return a handsome profit if devoted to this crop. The 1899 test with squashes was entirely satisfactory but as a single season's work is never a safe basis for a conclusion regarding any particular crop the test was repeated with the results recorded in table VIII. If, for sake of comparison, the value of the crop be reckoned at one cent per pound, the smallest yield that season would have returned $\$ 74.40$ per acre and the largest $\$ 230.95$. This is a verification of the results of the previous season. 
Table VII._Squashes. - 1899.

\begin{tabular}{|c|c|c|c|}
\hline VARIETY. & No. hills. & Vield. & Yield per acre. \\
\hline 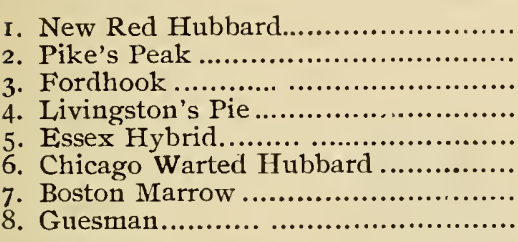 & $\begin{array}{l}9 . \\
9 . \\
9 . \\
8 . \\
9 . \\
9 . \\
9 . \\
9 .\end{array}$ & $\begin{array}{l}56.25 \\
165 . \\
132.25 \\
256.75 \\
250 \\
235 \\
175.25 \\
269.75\end{array}$ & 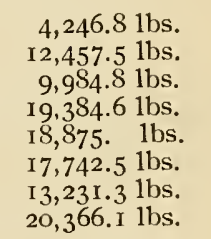 \\
\hline
\end{tabular}

Table VIII._Squashes. 1900.

\begin{tabular}{|c|c|c|c|}
\hline VARIETY. & No. hills. & Yield. & Yield per acre. \\
\hline Golden Hubbard.. & 22 & 654 & 20,274 lbs. \\
\hline Pike's Peak............. & 22 & 240 & 7,440 lbs. \\
\hline 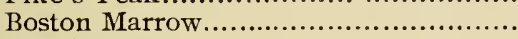 & 22 & 745 & 23,095 lbs. \\
\hline 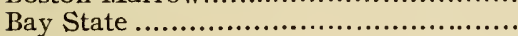 & 22 & 345 & 17,595 lbs. \\
\hline Hubbard..................................... & 22 & 550 & I 7,050 lbs. \\
\hline 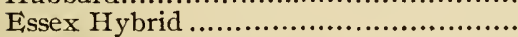 & 22 & 320 & $16,320 \mathrm{lbs}$. \\
\hline
\end{tabular}

In addition to the sorts shown in figure 6 and enumerated in tables VII and VIII, a collection of Cucurbits sent out by the Division of Seed and Plant Introduction of the U. S. Department of Agriculture were also grown. Table IX gives the accession numbers and names of these rare and peculiar fruits. Figure 5 gives an idea of the comparative size and form of these fruits. While some of them are exceedingly interesting in shape and possess many desirable features such as firm texture of shell or rind and long keeping qualities; the quality of most of them was such as to exclude them from the group of market sorts.

REMARKS ON NEW SORTS.

3132 Vegetable Marrow. - This plant, while not in all respects like the common cow pumpkin Cucurbita pepo, nevertheless belongs to the class as is shown by the fruit on top of the watermelon at the left in Fig. 5. This fruit is yellow in color and has the characteristic stem and creeping vine of the cow pumpkin. So far 
as one season's trial would indicate, the sort possesses no advantage over the common sorts now upon the market.

s138 Vegetable Marrow.--This plant, received under this name and number, is $C$. moschata as is evidenced both by the foliage and the stem of the fruit. It proved to be a strong grower and at the same time productive. The fruits as shown in Fig. 5, were either straight or curved, were green in color although the solor was shaded in such a way as to give the fruit a striped effect.

3134 Vegetable Marrow. - The seed received under this number prouluced fruits of two forms and colors as shown in Fig. 5. The one at the left being a light straw color while the one at the right was dark green. The straw colored specimens present marked lines or ridges running from stem to blossom end. Although the two forms are shown, both belong to $C$. pepa. The vine being of the bush type.

3136 Vegetable Marrow. - This as shown by the figure gave two types of fruits, one a small depressed fruit the other elongated; both were yellow in color and belong to $C$. pepo. The vine being a runner instead of belonging to the "bush" type which characterized most of the Cucurbits in the foreign collection this season.

Table IX.-New Cucurbits (from U. S. Dep't Agr.)

\begin{tabular}{|c|c|c|c|}
\hline & NUMBERS AND VARIETIES. & No. liills. & Yield in lbs. \\
\hline 3136 & Vegetable Marrow........................ & 4 & $S_{5}$ \\
\hline 3148 & Vegetable Marrow........................ & 4 & I09 \\
\hline 3134 & Vegetable Marrow........................ & 4 & 142 \\
\hline $313^{2}$ & Vegetable Marrow........................ & 4 & 69 \\
\hline 3133 & Vegetable Marrow........................ & 5 & 93 \\
\hline 4366 & Vegetable Marrow.......................... & 4 & 96 \\
\hline 4976 & Subb's set ale Gourd...................... & I & 93 \\
\hline 5002 & Cucurbita maxima ...................... & I & 63 \\
\hline 5001 & Cucurbita maxima ........................ & I & 123 \\
\hline 4993 & Cucumis melo.............................. & & Did not ripen. \\
\hline 3945 & Cucunis melo................................ & & Did not ripen. \\
\hline 4269 & Citrullus vulgaris . ....................... & 6 & A very large citron. \\
\hline
\end{tabular}

4366 Vegetable Marrow. - This proved to be a very remarkable plant as is shown by figure 5 which is a photograph of a single 


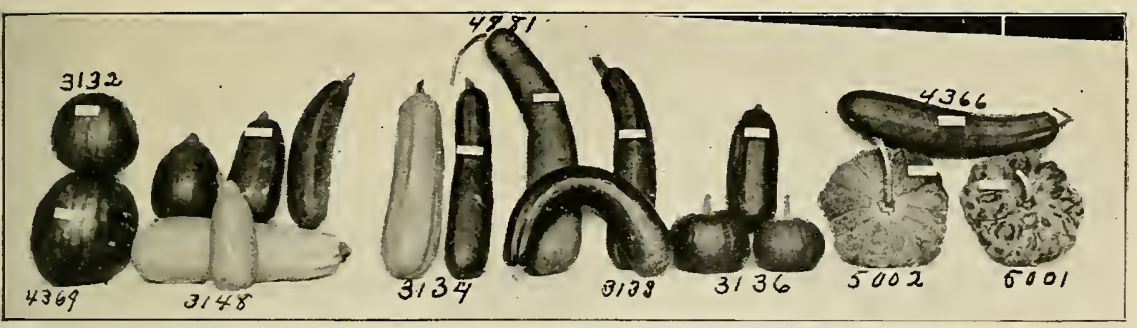

FIG. 5.--Cucurbrito named in table IX.

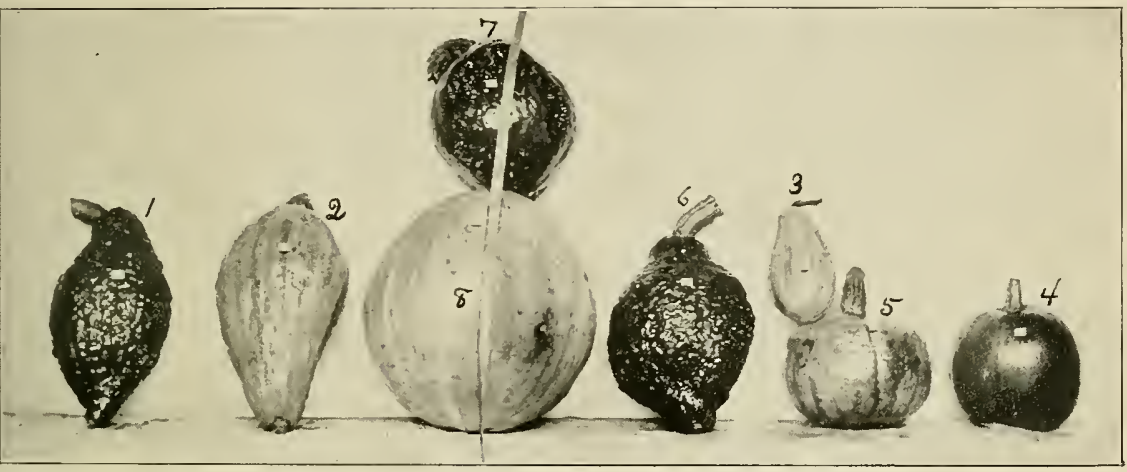

FIG. 6.-Squashes named in table VII.

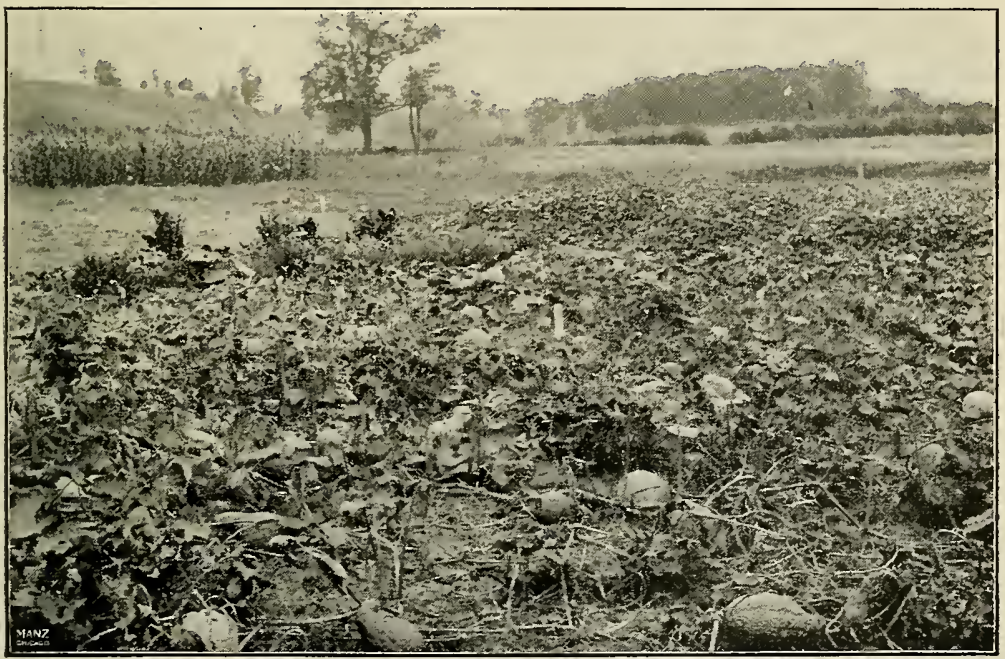

FIG. 7.-Squash plats in glade garden. 

speciman from a hill upon which fruits averaged nearly two feet in length and five inches in diameter. The specimen on top of the two squashes at the right in Fig. 5 is 21 inches long, yellow in color and belonging to the bush type of $C$. pepo.

\section{CULTURAL SUGGESTIONS.}

The field culture of the squash is so simple that any notes on the subject seem almost out of place. One precaution is necessary, however, the plant is very susceptił,le to injury by cold. The seeds should not be planted until the soil has become thoroughly warmed and all dal ger of killing frosts has passed. A safe date for the section under discussion is from May 15th to 20th. After the young plants appear above ground they are liable to be destroyed by the striped cucumber beetle or by the sçuash bug. Both these pests are very persistent and usually very abundant so that preparations for cuntrolling them should be made at or before planting time. A simple and effective protection for the young plants is afforded by mosquito netting. This can be used in small squares 18 by 18 inches. A srnall wooden pin six inches in height is placed in the middle of the hill of squashes and the mosquito netting placed over this so as to form a tent over the young plar.ts, and earth drawn over the edges of the cloth with a hoe. If the plants have been supplied with a liberal amount of well decomposed stable manure in the bottom of each hill, the young plants, if protected until the roots come in contact with this food supply will need little further attention as they will by this time have gained sufficient size and vigor to care for themselves. As the hills of squashes should be eight, feet apart each way with 680 to the acre it will cost only about $\$ 10.00$ per acre outlay for protecting cloth. In comparison with the results given by other treatments we are inclined to favor the use of the cloth above all others. Then too if care is exercised in gathering them as soon as they have served their purpose a large percentage of them will be found suitable for use a second year. A still more satisfactory protector can be made by nailing together 1 by 4 inch boards so as to make a frame 12 inches square. Cover this with woven wire screen such as is used in doors and windows and you have a durable and efficient pro- 
tecting device. The cost of such frames together with the large amount of room necessary to store them 11 months of the year is an itern to be taken into consideration in selecting a protective covering. Very satisfactory results nsually follow from the use of tobacco dust placed as a mulch about the young seedling plants. While this is undoubtedly one of the most satisfactory insecticides which can be used for combating these pests, it is not as satisfactory as the protectors.

\section{HARVESTING AND STORING.}

Squashes if properly cared for can be kept from harvest time in October until the following $A$ pril. In order to succeed in storing the fruits. however, they must receive the most careful treatment They should never be bruised or scarred, never piled on top of one ancther, and the stems preserved intact. Besides this, the fruits, as soon as removel from the vine, should be stored in a well ventilated building which will at the same time admit of being maintained at a uniform temperature of $40 \mathrm{~F}$. from November until the end of the storage period. The most satisfactory storage rooms are provided with shelves placed one above the other upon which a single layer of squashes snly are placed, aisles are left between the tiers of shelves to allow of installing and removing the squashes and so arranged as to provide for easily heating the air space during cold periods. When practicahle it is usually found to be best economy to market the product direct from the field. The sareful handling necessary with the cost of the building necessary to properly house such a bulky crop will be found to be large items in the cost of preservation, and to justify this the crop must sell for a decided alvance over the price at harvest time. 


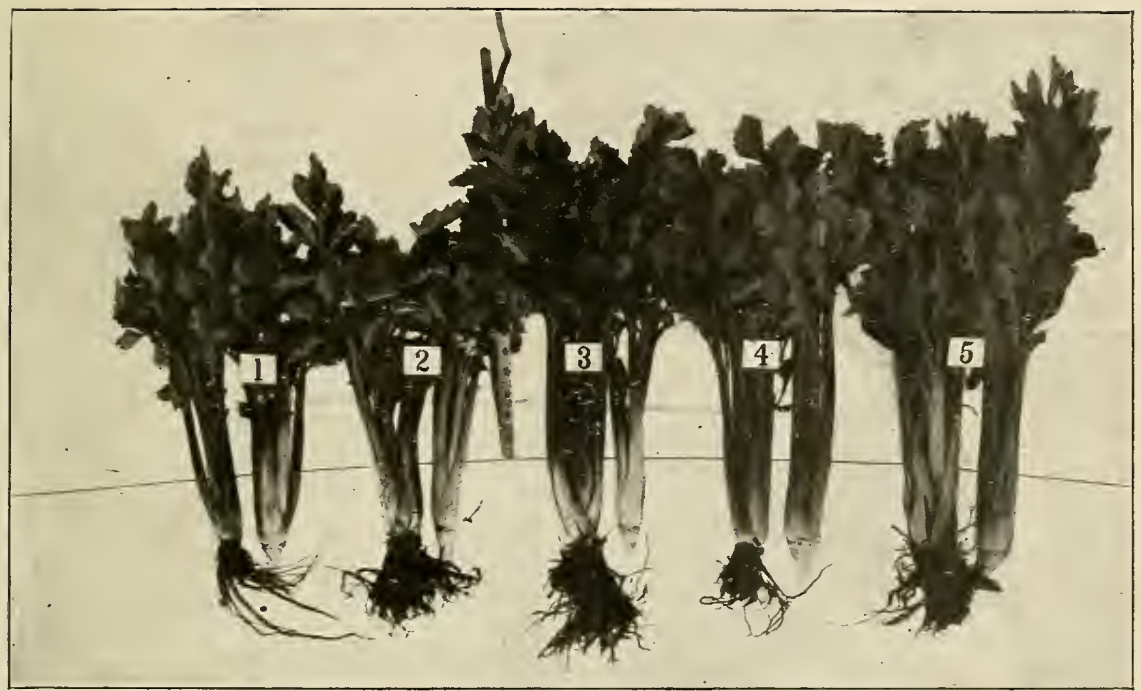

FIG. 8.-Celery ISg9.

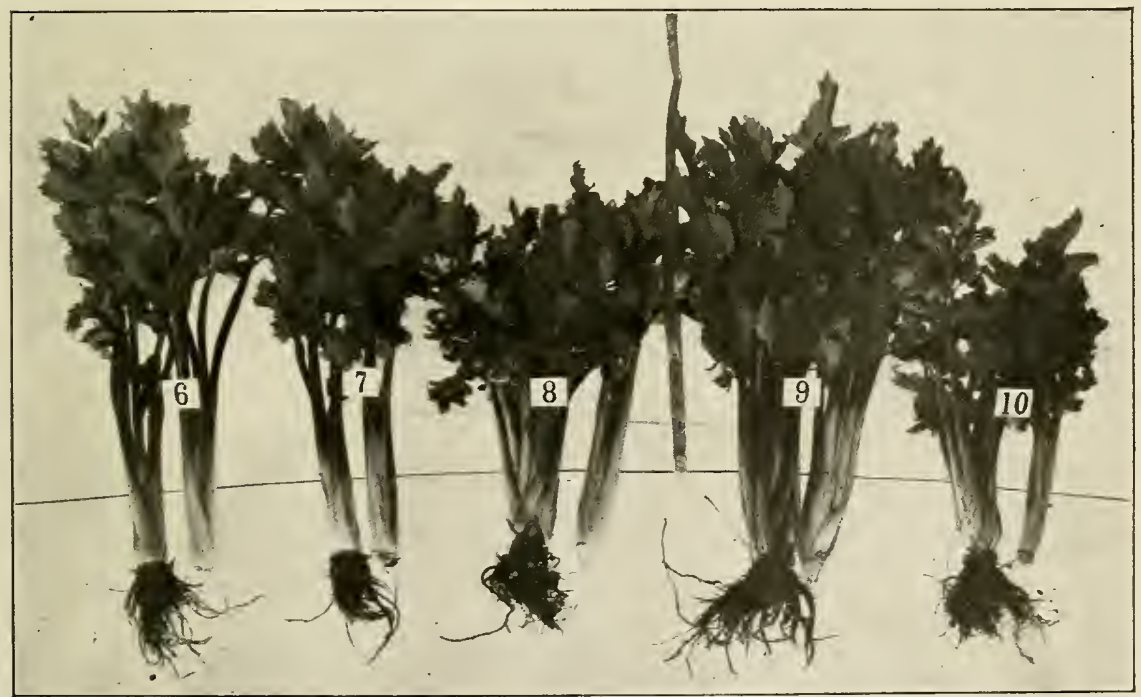

FIG. 9.-Celery I899. 



\section{CELERY.}

The cultivation of celery in the United States is at present largely confined to two or three regions Two of these especially noted for this crop are the Kalamazon region near the town of K،llamazoo, Michigan and the Horse Heads region of Chemung county, N. Y. Both these districts are pre eminently suited to the culture of this crop both from climate and soil conditions. Notwithstanding the renown of the above named districta, celery grown on the glade-lands of the Allegheny Mountains received the highest arard at the World's Columbian Exposition at Chicago in 1893. The physical nature of the glade-lands is similar to that of the two regions above mentioned, and tie quality of the product which can be grown thereon has been determined by the competition of 1893 .

The question before us is to seek out the methods of culture and combinations of fertilizers demanded by these soils in order to produce this high grade product. Second, Cau celery be successfully grown upon these soils with the use of chemical fertilizers alone? Third, Can the celery blight be successfuliy controlled by the use of sprays?

The work with celery up to the present, (1900) has not proven altogether satisfactory. The soil conditions which best favor the growth of the crop have not yet been determined and at this time a report of progress of the work with this crop can only be given. 
While the soil appears to be in perfect mechanical condition for the development of the celery plant it does not contain a sufficient amount of available plant food to force the crop to profitable maturity. Lime at the rate of 30 bushels per acre as well as these two chemical fertilizers were used:

First:-

250 lbs. Nitrate Soda, N 5 per cent.

400 lbs. Acid Phosphate, $\mathrm{P}_{2} \mathrm{O}_{5} 6$ per cent.

130 lbs. Muriate Potash, K 8 per cent.

Second:-

30 lbs. Nitrate Soda, N 8 per cent.

400 lbs. Acid Phosphate, $\mathrm{P}_{2} \mathrm{O}_{5} 7$ per cent.

100 lbs. Muriate Potash, K 6 per cent.

These amounts per acre seem to do little towards providing the crop with the needed food supply. The most encouraging results so far attained were given this season, (1900) on the Stable Manure plat where 20 tons of Stable Mauure per acre were applied. This soil is thoroughly tile drained and may, therelore, contain too little moisture for the best results from the chemicle fertilizers. The indications during 1900, a very dry season as compared with 1899, at year of average rainfall, favors this supposition. This year, (1900) celery on the plat with chemical fertilizers was little larger September 20th, than when planted in the field June 27th: while the crop on the stable manure plat was ready for market, the plants having made a good stand and produced a fair market product with stalks averaging 12 to 15 inches in length. In 1899 it was not $p$ sssible to compare the fertilizer and stable manure as only chemical fertilizers were used, but with normal rainfall the chemival fertilizers produced a crop averaging better than that returned by the stable manure during the season of 1900 .

Figures 8 and 9 will serve to indicate the behavior of the various sorts grown with chemical manure during the season of 1899 . In quality the product of 1899 was high, the stalks were bright, crisp and deliciously nutty in flavor. The size of the plants, too, while not the largest, was sufficient to satisfy the market. While the crop of 1899 was a comparative success as was also that grown 
with stable manure in 1900 , we do not as yet, feel that the local conditions are sufficiently well understood to warcant any general statements or recommendations regarding the best practices for commercial work. At present we are inclined to believe that heavy manuring by turning under leguminous crops, combined with an appliciation of 40 tons or more of well rotted stable manure per acre will give a large and paying crop of celery. The one drawback up to date has been to get the plants to make a satisfactory growth immediately after transplanting them to the field, particularly on those areas where commercial fertilizers alone were used, less difficulty in this respect was experienced on areas treated liberally with stable manure.

\section{COMMERCIAL PRACTICES.}

While many schemes for growing celery on a small scale have been devised, and while many of them are of great value where only a limited land area is at one's dispozal; yet for extensive field operations there is probably no system of culture which is more to be relied upon than that of starting the young plants in a cold frame, transplanting them when one and a half iuches high so as to stand about one inch apart, in rows three inches apart, and to protect them with sash or plant clcth at right so long as there is danger of any check to the growth of the young plants by frost. If the plants grow rapidly and have a tendency to draw. the protection should be entirely removed during the day and the tops of the plants sheared off to make the growth more stocky. At planting time the plants may be set in single rows three feet apart, with the plants six inches apart in the row, or they may be set in a double row six inches wide, and the plants six inches apart in the row with the rows six feet apart. Constant shallow culture should be given to induce a steady healthy growth. As the soason advances and cool weather comes on growth will be more active and cultivation should be continued to stimulate this late growth. If the crop is intended for immediate consumption which is most desirable the blanching operation should be begun about ten days or two weeks before the crop is to be marketed. The quantity banked should correspond to the quantity to be shipped each day in order 
that all shall have been banked a like period. This precaution is of the utmost importance in caring for the summer crop which of necessity has to be blanched during hoit weather. At that season the blanching period should be reduced to six or eight days. Longer banking is liable to cause heavy loss in the crop. In field operations earth will be found to be the most economical and satisfactory material for blanching the late crop. See Figure 10. For the early crop boards possess advantages but unless very carefully used they are apt to produce an evil result. The celery becomes dry and pithy and not unfrequently takes up a resinous flaver from the boards, particularly if new pine boards are used. For small plantarions heavy brown paper can be used as a substitute for boards with good results. In still smaller cases 3 or 4 inch agrieultural tiles slipped down over the plants will accomplish the desired end in a very satisfactory manner.

\section{STORAGE.}

Celery preserves its texture and flavor best when stored in sheds or pits. These are constructed with the sides 2 to $2 \frac{1}{2}$ fect high. made of boards or plank. In scme cases they are made of railroad ties cut half in two and set like posts about 18 inches deep in a trench which allows them to be placed close together. A flat roof structure is then made of boards and suitable ventilators left along the ridge, which insure good ventilation at all times. The celery is then packed away in boxes of convenient size or removed with earth on the roots and packed in sand in rows as it stood in the field. Place the rows about one foot apart and the plants close together in the row. The sand should be kept moist but no water should ever be allowed to come in contact with the foliage while the crop is in store. Storage is an expensive operation both as regards labor and equipment. If the crop can be marketed from the field, so much the better, as much labor and expense will be saved therehy. 


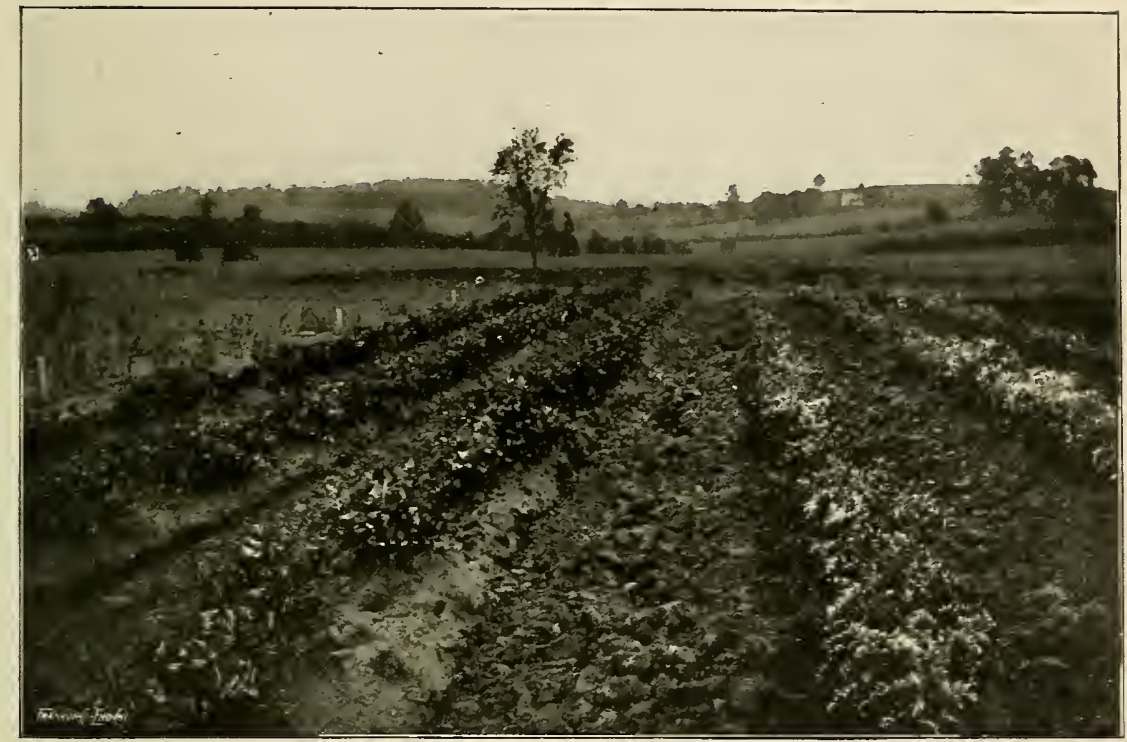

FIG. Io.-Blanching late celery. 


